\title{
Iodinating Activity of Thyroid Tissue in Toxic Diffuse Goiter
}

\author{
Shigenobu Nagataki, Hidemasa Uchimura, Hitoshi Ikeda, Nobuaki KuzUya, \\ Yuko Masuyama, Lindy F. Kumagai, and Kunihiko Ito \\ From the Third Department of Internal Medicine, Faculty of Medicine, University of Tokyo, \\ Hongo, Tokyo, and Ito Hospital, Shibuya-ku, Tokyo, Japan
}

\begin{abstract}
A B S T RACT Thyroid tissue obtained from 12 patients with Graves' disease and treated with thionamide drugs for 3-7 mo before subtotal thyroidectomy, from 12 patients with Graves' disease, similarly treated, and given $50 \mu \mathrm{g}$ of triiodothyronine $\left(\mathrm{T}_{3}\right)$ for 10 days before surgery, and from 12 euthyroid patients with solitary cold nodules was investigated to compare in vitro iodination of thyroglobulin in toxic diffuse goiter and in normal thyroid tissue. The supernates of the homogenates $(105,000 \mathrm{~g})$ were subjected to sucrose density gradient centrifugation $(5-28 \%)$ to separate the thyroglobulin fraction. The precipitates were treated with $1 \%$ digitonin and centrifuged to collect the supernate (particulate fraction). When thyroglobulin and particulate fractions obtained from the same patient were incubated with ${ }^{125} \mathrm{I}^{-}$, iodide, glucose, and glucose oxidase, the amount of iodine bound to thyroglobulin was several times greater in toxic diffuse goiter than in normal thyroid tissue; administration of $\mathrm{T}_{3}$ did not affect iodination in toxic diffuse goiter. When the thyroglobulin fraction from each patient was incubated with a standardized quantity of peroxidase instead of the individual particulate fraction, the amount of iodine bound to thyroglobulin was the same among the three groups of patients. Finally, when bovine serum albumin was substituted for thyroglobulin from each of the patients, iodination of bovine serum albumin was several times greater with the particulate fraction obtained from toxic diffuse goiter tissue than with that obtained from normal
\end{abstract}

This work was presented in part at the 57th Annual Meeting of the American Endocrine Society, New York, June 1975.

Dr. Uchimura's present address is the Department of Medicine, Beth Israel Hospital, Boston, Mass. 02215. Dr. Kumagai's present address is the Department of Internal Medicine, University of California, Davis, School of Medicine, Davis, Calif. 95616.

Received for publication 30 August 1976 and in revised form 4 December 1976. tissue. The guaiacol-oxidizing activity of the particulate fraction was found to be parallel to the iodination activity. These results suggest that in vitro iodination of thyroglobulin is increased in toxic diffuse goiter even when patients are made euthyroid by treatment with thionamide drugs as well as when they are given additional $T_{3}$ for 10 days before operation. The increase in iodination of thyroglobulin appears to be due to an increase in peroxidase activity in the particulate fraction.

\section{INTRODUCTION}

The pathogenesis of Graves' disease is still not clear in spite of the extensive efforts of numerous investigators. The etiology may be an extrathyroidal stimulator or the basic defect may be intrathyroidal. Regardless of the primary etiology, it is of interest to elucidate some of the essential changes within the thyroid which may relate to the possible mechanism of increased thyroid hormone synthesis in Graves' disease. The present experiments were undertaken to observe in vitro iodination of thyroglobulin using various intrathyroidal components obtained from thyroid tissue of patients with Graves' disease, and compared with tissue obtained from euthyroid patients with solitary cold nodules.

\section{METHODS}

Thyroid tissue was obtained from (a) 12 patients with Graves' disease who had been treated with thionamide drugs for 3-7 mo before subtotal thyroidectomy, (b) 12 patients with Graves' disease similarly treated and given $50 \mu \mathrm{g}$ of triiodothyronine $\left(\mathrm{T}_{3}\right)^{1}$ for 10 days before the operation, and (c) 12 patients with solitary nonfunctioning adenoma or carcinoma. Graves' disease was diagnosed from the clinical features of thyrotoxicosis and the laboratory tests; serum

\footnotetext{
${ }^{1}$ Abbreviations used in this paper: $\mathrm{T}_{3}$, triiodothyronine; $\mathrm{T}_{4}$, thyroxine; $\mathrm{TSH}$, thyrotropin.
} 
thyroxine $\left(\mathrm{T}_{4}\right)>14.5 \mu \mathrm{g} / 100 \mathrm{ml}, \mathrm{T}_{3}$ resin uptake $>35 \%$, serum $\mathrm{T}_{3}>1.8 \mathrm{ng} / \mathrm{ml}$. All patients studied were euthyroid before surgery and none were given preoperative iodine treatment. Serum concentrations of $T_{4}, T_{3}$, and basal thyrotropin (TSH) were within normal limits in all patients at the time of operation or immediately before $T_{3}$ administration.

\section{General procedure}

Thyroid tissue obtained during surgery was quickly frozen and $500-\mathrm{mg}$ aliquots were homogenized in $2.5 \mathrm{ml}$ of cold saline in glass homogenizers at $1,000 \mathrm{rpm}$ for $1 \mathrm{~min}$. The homogenization was interrupted every $15 \mathrm{~s}$ to permit chilling of the homogenate for $10 \mathrm{~s}$ in ice water.

After $0.1 \mathrm{ml}$ of the homogenate had been removed for DNA determinations, the homogenates were transferred to glass tubes and then centrifuged at $600 \mathrm{~g}$ for $10 \mathrm{~min}$. $1-\mathrm{ml}$ aliquots of the supernates were transferred to polycarbonate tubes and diluted with $1 \mathrm{ml}$ of saline, and additional $1-\mathrm{ml}$ aliquots were transferred to cellulose nitrate tubes and diluted to $13.5 \mathrm{ml}$ with saline. Ultracentrifugation of both dilutions was carried out for $30 \mathrm{~min}$ in a Beckman model L2-65B centrifuge with type 40 rotor (Beckman Instruments, Inc., Fullerton, Calif.), at a centrifugal force of $105,000 \mathrm{~g}$. The supernates of the former dilution were then frozen and stored for future isolation of thyroglobulin while the pellets were used for solubilizing peroxidase. The supernates of the latter dilution were discarded and the pellets were stored frozen for the determination of peroxidase activity by guaiacol-oxidizing activity.

\section{Purification of thyroglobulin}

Purification of thyroglobulin was carried out by sucrose density gradient centrifugation $(1,2) .0 .3 \mathrm{ml}$ of the $105,000 \mathrm{~g}$ supernate was layered carefully on top of the sucrose gradient $(5-28 \%$ in $0.05 \mathrm{M}$ sodium phosphate buffer, $\mathrm{pH} 7.4)$ in a 5-ml Spinco tube (Beckman Instruments, Spinco Div., Palo Alto, Calif.), and centrifuged in the SW $50 \mathrm{~L}$ rotor at 35,000 rpm for $15-16 \mathrm{~h}$ in a Beckman model L2-65B centrifuge. After centrifugation, the bottom of the centrifuge tube was punctured and consecutive 10-drop fractions were collected. After appropriate dilution, the total protein content of each fraction was determined by the method of Lowry et al. (3). Fractions equivalent to 19S (determined using ${ }^{131}$ I-labeled rat thyroglobulin) were pooled and diluted with phosphate buffer to a concentration of $1 \mathrm{nmol} / 0.2 \mathrm{ml}$. These fractions were used as the thyroglobulin fraction.

\section{Solubilization of thyroid peroxidase}

Solubilization of thyroid peroxidase was carried out by treatment with $1 \%$ digitonin $(4,5)$. The $105,000 \mathrm{~g}$ pellets were suspended with $0.8 \mathrm{ml}$ of $0.05 \mathrm{M}$ phosphate buffer, $\mathrm{pH}$ 7.0, containing $1 \%$ digitonin and were incubated for 30 $\mathrm{min}$ in ice water before centrifugation at $105,000 \mathrm{~g}$ in polycarbonate tubes. The supernate of digitonin-treated pellets (which contains most of the peroxidase activity in thyroid tissue [6]) was used without further purification.

\section{In vitro iodination of thyroglobulin}

In vitro iodination of thyroglobulin was carried out by a method similar to that described by Taurog (7). The complete system for in vitro iodination of thyroglobulin consisted of the peroxidase fraction obtained from $50 \mathrm{mg}$ of tissue, $1.0 \mathrm{nmol}$ of thyroglobulin obtained from each patient, $10 \mathrm{nmol}$ of $\mathrm{NaI}, 0.05 \mu \mathrm{Ci}$ of $\mathrm{Na}^{125} \mathrm{I}, 1.0 \mathrm{mg}$, of glucose, and $0.83 \mu \mathrm{g}$ of glucose oxidase (G-6125, purified type II, 14,650 U/g solid, Sigma Chemical Co., St. Louis, Mo.) in a total volume of $1.0 \mathrm{ml}$ of $0.05 \mathrm{M}$ phosphate buffer, $\mathrm{pH}$ 7.0. Incubation was for $1 \mathrm{~h}$ at $37^{\circ} \mathrm{C}$. At the end of incubation, $0.1 \mathrm{ml}$ of $0.1 \mathrm{M}$ methimazole was added to stop the reaction, and the separation of protein-bound and inorganic ${ }^{125}$ I was carried out by paper chromatography in a butanolethanol-0.5 M ammonia system (5:1:2). Since thyroglobulin was purified by sucrose density gradient centrifugation, the thyroglobulin fraction contained high concentrations of sucrose. However, iodination of bovine serum albumin with lactoperoxidase was not affected by $0.25 \mathrm{M}$ sucrose (unpublished data).

\section{Assays of peroxidase activity}

Iodinating activity. Activity of the peroxidase fraction was determined by the method used for in vitro iodination of thyroglobulin, except that $660 \mu \mathrm{g}$ of bovine serum albumin was substituted for thyroglobulin as a standard protein to act as an iodine acceptor.

Guaiacol-oxidizing activity. The rate of oxidation of guaiacol was followed spectrophotometrically on a Beckman DB-G spectrophotometer at $470 \mathrm{~nm}(5,6)$. The $105,000 \mathrm{~g}$ pellet was suspended in $0.8 \mathrm{ml}$ of $0.2 \mathrm{M}$ phosphate buffer, $\mathrm{pH} 7.4$, and $0.2 \mathrm{ml}$ of the suspension, 1.0 $\mathrm{ml}$ of $0.1 \mathrm{M}$ guaiacol, and $1.6 \mathrm{ml}$ of phosphate buffer were mixed in a cuvette with a 1.0-cm light path, and the absorbance at $470 \mathrm{~nm}$ was set at zero. The reaction was begun with the addition of $10 \mu \mathrm{l}$ of $88 \mathrm{mM} \mathrm{H}_{2} \mathrm{O}_{2}$, and the change in absorbance was recorded. The assay was performed at room temperature.

As had been reported previously (6), the dose response curve of peroxidase is not linear and it is necessary to express peroxidase activity in terms of an equivalent amount of standard enzyme. The standard enzyme employed for the guaiacol assay was horse radish peroxidase (15,302, grade II, $100 \mathrm{U} / \mathrm{mg}$, Boehringer Mannheim Corp., New York) and lactoperoxidase (L-8,503, 43 purpurogallin U/mg solid, Sigma Chemical Co.) for the iodinating activity assay.

\section{Determination of DNA content in thyroid homogenates}

The colorimetric estimation of DNA was carried out according to the method described by Burton (8). $0.1 \mathrm{ml}$ of the homogenate was mixed with $4 \mathrm{ml}$ of $0.5 \mathrm{~N} \mathrm{HClO}_{4}$ and centrifuged at $4^{\circ} \mathrm{C}$ after chilling for $30 \mathrm{~min}$. The supernate was discarded and the precipitate was washed with $4 \mathrm{ml}$ of $\mathrm{HClO}_{4}$. The precipitate was broken up with a glass rod and stirred with $3 \mathrm{ml}$ of $0.5 \mathrm{~N} \mathrm{HClO}_{4}$, and the suspension was heated at $70^{\circ} \mathrm{C}$ for $15 \mathrm{~min}$ with occasional stirring. After cooling at room temperature, the suspension was centrifuged for $30 \mathrm{~min}$ and $1 \mathrm{ml}$ of the supernate was mixed with $2 \mathrm{ml}$ of diphenylamine reagent containing acetaldehyde. Diphenylamine reagent was prepared by dissolving $1.5 \mathrm{~g}$ of diphenylamine (Koso Chemical Co. Ltd., Tokyo, Japan) in $100 \mathrm{ml}$ of acetic acid and adding $1.5 \mathrm{ml}$ of concentrated. $\mathrm{H}_{2} \mathrm{SO}_{4}$. On the day it is to be used, $0.1 \mathrm{ml}$ of $16 \mathrm{mg} / \mathrm{ml}$ aqueous acetaldehyde was added for each $20 \mathrm{ml}$ of reagent required. Tubes containing known amounts of standard DNA (highly polymerized calf thymus DNA, Sigma Chemical Co.) and a blank containing $0.5 \mathrm{~N} \mathrm{HClO}_{4}$ with no DNA were also 
TABLE I

Iodinating Activity of Thyroid Tissue in Toxic Diffuse Goiter

\begin{tabular}{|c|c|c|c|c|c|c|c|c|}
\hline $\begin{array}{l}\text { Thyroid } \\
\text { tissue* }\end{array}$ & Patient & Sex & Age & $\begin{array}{c}\text { Iodinating } \\
\text { activity }\end{array}$ & Serum $T_{4} \S$ & Serum TSH\$ & Serum $T_{3} s$ & Treatment \\
\hline & & & & $\%$ & $\mu \mathrm{g} / 100 \mathrm{ml}$ & $\mu C / m l$ & $n g / m l$ & $m g / d a y$ \\
\hline \multirow[t]{14}{*}{ Normal } & 1 & $\mathbf{F}$ & 51 & 9.0 & 7.2 & 2 & 1.1 & \\
\hline & 2 & $\mathbf{F}$ & 25 & 9.0 & 9.5 & 3 & 0.9 & \\
\hline & 3 & $F$ & 20 & 8.9 & 11.2 & 2 & 1.4 & \\
\hline & 4 & $\mathrm{~F}$ & 40 & 8.2 & 11.4 & ND & 1.4 & \\
\hline & 5 & $\mathbf{F}$ & 40 & 8.2 & 10.7 & ND & 1.4 & \\
\hline & 6 & $\mathbf{F}$ & 30 & 8.1 & 7.5 & ND & 0.9 & \\
\hline & 7 & $\mathbf{M}$ & 42 & 8.0 & 10.3 & ND & 1.3 & \\
\hline & 8 & $\mathbf{F}$ & 31 & 7.9 & 9.7 & 2 & 1.1 & \\
\hline & 9 & $\mathbf{F}$ & 30 & 7.0 & 10.0 & ND & 1.0 & \\
\hline & 10 & $\mathbf{F}$ & 27 & 6.1 & 5.9 & 2 & 1.1 & \\
\hline & 11 & $\mathbf{F}$ & 25 & 5.8 & 8.0 & 3 & 1.2 & \\
\hline & 12 & $\mathrm{~F}$ & 26 & 5.8 & 11.3 & 3 & 1.3 & \\
\hline & & Me & & 7.7 & 9.4 & - & 1.2 & \\
\hline & & \pm & & 0.3 & 0.5 & - & 0.05 & \\
\hline \multirow[t]{16}{*}{ Graves' } & 1 & $\mathbf{M}$ & 22 & 65.2 & 5.6 & ND & 1.2 & M 20 \\
\hline & 2 & $\mathbf{F}$ & 24 & 51.6 & 7.8 & 2 & 1.1 & M 10 \\
\hline & 3 & $F$ & 26 & 48.6 & 5.6 & 7 & 1.0 & M 10 \\
\hline & 4 & $\mathrm{~F}$ & 30 & 47.7 & 5.3 & 8 & 0.9 & M 10 \\
\hline & 5 & $\mathbf{M}$ & 19 & 44.3 & 9.7 & 6 & 0.9 & M 15 \\
\hline & 6 & $\mathbf{M}$ & 24 & 37.6 & 8.8 & ND & 1.0 & M 10 \\
\hline & 7 & $\mathbf{F}$ & 20 & 18.2 & 6.0 & ND & 1.1 & M 10 \\
\hline & 8 & $\mathbf{F}$ & 41 & 9.9 & 11.2 & ND & 1.9 & M 20 \\
\hline & 9 & $\mathrm{~F}$ & 18 & 9.0 & 6.0 & ND & 1.3 & M 30 \\
\hline & 10 & $\mathrm{~F}$ & 23 & 7.4 & 7.8 & ND & 1.5 & M 20 \\
\hline & & \multirow{2}{*}{\multicolumn{2}{|c|}{$\begin{array}{l}\text { Mean (10) } \\
\pm S E(10)\end{array}$}} & 34.0 & 7.4 & - & 1.2 & - \\
\hline & & & & 6.6 & 0.6 & - & 0.1 & - \\
\hline & 11 & $\mathbf{F}$ & 22 & 41.3 & 10.0 & ND & 1.6 & P 45 \\
\hline & 12 & $\mathbf{F}$ & 33 & 26.1 & 8.9 & ND & 1.0 & P 45 \\
\hline & & \multirow{2}{*}{\multicolumn{2}{|c|}{$\begin{array}{l}\text { Mean (12) } \\
\pm S E(12)\end{array}$}} & 33.9 & 7.7 & - & 1.2 & - \\
\hline & & & & 5.6 & 0.6 & - & 0.1 & - \\
\hline Graves' & 1 & $\mathrm{~F}$ & 28 & 72.4 & 9.3 & ND & 2.8 & M 20 \\
\hline \multirow[t]{13}{*}{$+\mathrm{T}_{3}$} & 2 & $\mathbf{F}$ & 21 & 59.0 & 6.8 & ND & 1.5 & M 10 \\
\hline & 3 & $\mathrm{~F}$ & 39 & 51.9 & 8.3 & ND & 2.8 & M 5 \\
\hline & 4 & $\mathrm{~F}$ & 19 & 49.3 & 6.1 & ND & 1.4 & M 15 \\
\hline & 5 & $\mathrm{~F}$ & 23 & 47.2 & 5.8 & ND & 2.1 & M 10 \\
\hline & 6 & $\mathrm{~F}$ & 22 & 13.0 & 10.4 & ND & 2.8 & M 15 \\
\hline & 7 & $\mathbf{M}$ & 25 & 11.5 & 11.5 & ND & 2.5 & M 20 \\
\hline & 8 & $\mathrm{~F}$ & 25 & 10.9 & 8.6 & ND & 2.8 & M 20 \\
\hline & 9 & $\mathrm{~F}$ & 30 & 7.3 & 11.8 & ND & 3.5 & M 15 \\
\hline & 10 & $\mathrm{~F}$ & 19 & 6.6 & 6.3 & ND & 2.9 & M 10 \\
\hline & 11 & $\mathrm{~F}$ & 29 & 6.4 & 8.0 & ND & 2.5 & M 15 \\
\hline & 12 & $\mathbf{F}$ & 23 & 4.0 & 5.7 & ND & 2.7 & M 10 \\
\hline & & \multirow{2}{*}{\multicolumn{2}{|c|}{$\begin{array}{l}\text { Mean } \\
\pm S E\end{array}$}} & 28.3 & 8.2 & - & 2.5 & - \\
\hline & & & & 7.3 & 0.6 & - & 0.2 & - \\
\hline
\end{tabular}

* Normal: normal thyroid tissue obtained from patients with solitary cold nodules. Graves': thyroid tissue obtained from patients with Graves' disease treated with thionamide drugs before subtotal thyroidectomy. Graves' $+\mathrm{T}_{3}$ : thyroid tissue obtained from patients with Graves' disease similarly treated and given $50 \mu \mathrm{g}$ of $\mathrm{T}_{3}$ for $\mathbf{1 0}$ days before surgery.

$\ddagger$ Iodinating activity of thyroid tissue using the thyroglobulin and peroxidase fractions obtained from the same patients. The extent of iodination is expressed as percent of ${ }^{125}$ I bound to thyroglobulin.

\$Serum concentrations at the time of operation. Normal ranges are $T_{4}: 5.3-14.5 \mu \mathrm{g} / 100 \mathrm{ml}$, $\mathrm{TSH}:<10 \mu \mathrm{U}, \mathrm{T}_{3}: 0.8-1.8 \mathrm{ng} / \mathrm{ml}$.

" Doses of thionamide drugs at the time of operation. M, methimazole: P, propylthiouracil. 


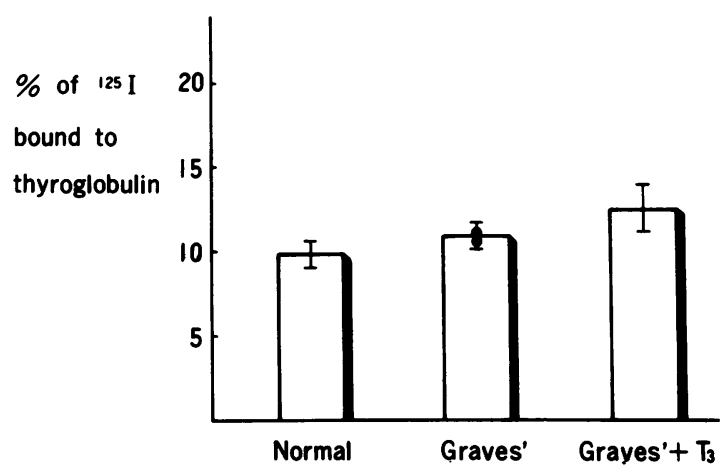

FIGURE 1 In vitro iodination of thyroglobulin using the thyroglobulin fraction from each patient and a standardized quantity of peroxidase extracted from pooled thyroid tissue of patients with Graves' disease. (Normal) Normal thyroid tissue obtained from patients with solitary cold nodules. (Graves') Thyroid tissue obtained from patients treated with methimazole before subtotal thyroidectomy. (Graves' $+\mathrm{T}_{3}$ ) Thyroid tissue obtained from patients with Graves' disease similarly treated and given $50 \mu \mathrm{g}$ of $\mathrm{T}_{3}$ for 10 days before surgery. The bars and lines represent the means $\pm S E$. Solid circles represent values obtained from two patients with Graves' disease treated with propylthiouracil.

prepared. The color was developed by incubating at $30^{\circ} \mathrm{C}$ for $16 \mathrm{~h}$. The absorbance at $600 \mathrm{~nm}$ was measured against the blank and compared with values obtained with standard DNA.

\section{RESULTS}

In vitro iodination of thyroglobulin using the thyroglobulin and peroxidase fractions obtained from the same patients. In Table I are shown the iodinating activity of thyroid tissue (expressed as percent of ${ }^{125}$ I bound to thyroglobulin), serum concentrations of $\mathrm{T}_{4}, \mathrm{TSH}$, and $\mathrm{T}_{3}$ at the time of operation, and the doses of thionamide drugs before surgery in the three groups of patients. Only 2 of the 24 patients with Graves' disease were treated with propylthiouracil and these results are shown separately in Table I. Values for iodinating activity obtained from thyroid tissue of patients with Graves' disease treated with methimazole were significantly greater than those from normal thyroid tissue $(P<0.01)$, and values in patients treated with propylthiouracil were very similar to that with methimazole. Values obtained from tissue of Graves' disease patients were the same regardless of whether or not the patients were treated with $T_{3}$ for 10 days before the operation $(P>0.05)$. However, three patients in the group of Graves' and four patients in the group of Graves' $+T_{3}$ showed normal iodinating activity when the normal range was defined by the means \pm 2 SD $(7.7 \pm 2.4)$ of values obtained from normal thyroid tissue.
Since the thyroglobulin and the peroxidase fractions in this system were obtained from the same patients, other experiments were carried out to determine which of the two fractions was responsible for the increase in iodination of thyroglobulin. In the following experiments, the results obtained from patients treated with methimazole are expressed as the means $\pm \mathrm{SE}$, but the results from two patients treated with propylthiouracil are shown individually.

In vitro iodination of thyroglobulin using the thyroglobulin fraction from each patient and a standardized peroxidase. To elucidate whether the thyroglobulin fraction was responsible for the increased iodination of thyroglobulin, the system in this experiment consisted of thyroglobulin from each patient and a standardized quantity of peroxidase extracted from pooled thyroid tissue of patients with Graves' disease. As shown in Fig. 1, there was no significant difference in iodination of thyroglobulin among the three groups of patients, indicating that the thyroglobulin fraction did not play a major role in increasing iodination in Graves' disease.

Peroxidase activity by the iodination assay. To observe the role of the peroxidase fraction, the system in this experiment consisted of the peroxidase fraction from each patient and bovine serum albumin which was substituted for thyroglobulin. This system was the same as that which was used in the method to determine peroxidase activity described by Taurog (7). Values were expressed as peroxidase activity in terms of an equivalent amount of lactoperoxidase. Peroxidase activity in tissue obtained from patients with Graves' disease treated with methimazole was significantly greater than that found in normal thyroid tissue $(P<0.01$ in micrograms lactoperoxidase per gram tissue, $P<0.02$ in micrograms lactoperoxidase per milligram DNA). Values from patients treated with propylthiouracil were similar to those from methimazole-treated patients. Administration of $T_{3}$ did not affect the peroxidase activity in Graves' disease regardless of whether the activity was expressed as micrograms of lactoperoxidase per gram thyroid tissue or per milligram of DNA ( $P>0.05)$ (Fig. 2). Therefore, the peroxidase fraction appears to be primarily responsible for increased iodination of thyroglobulin in Graves' disease.

Peroxidase activity by the guaiacol assay. Peroxidase activity in thyroid tissue was also determined by guaiacol-oxidizing activity, using horse radish peroxidase as standard enzyme. Similar to the iodinating activity, guaiacol-oxidizing activity in tissue obtained from patients with Graves' disease was significantly greater than that observed in normal tissue and the prior administration of $\mathrm{T}_{3}$ did not affect 


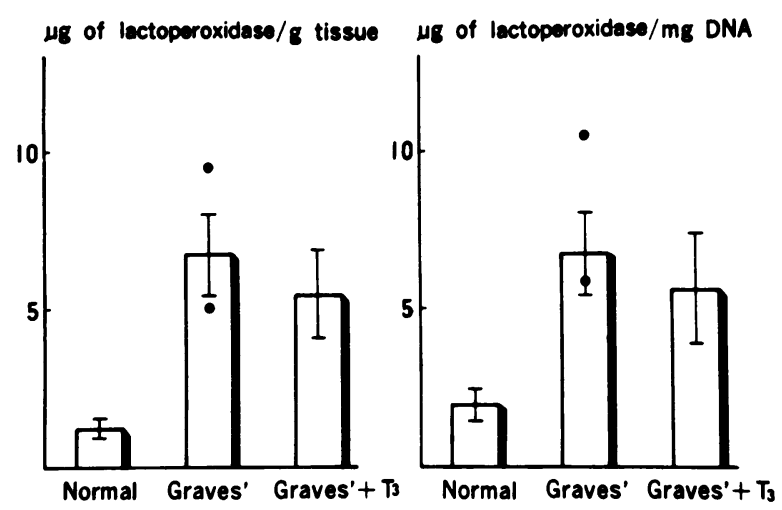

FIGURE 2 Peroxidase activity as iodinating activity. Values are expressed in terms of an equivalent amount of lactoperoxidase.

the activity. The difference was significant when guaiacol-oxidizing activity was expressed as micrograms of horse radish peroxidase per gram of tissue $(P<0.01)$ or per milligram of DNA $(P<0.05)$ (Fig. 3).

\section{DISCUSSION}

In the present experiments, in vitro iodination of thyroglobulin using the thyroglobulin and peroxidase fractions obtained from the same patients was increased in Graves' disease even when patients were made euthyroid by treatment with thionamide drugs and also when an additional $50 \mu \mathrm{g}$ of $\mathrm{T}_{3}$ was given for 10 days before surgery. These results agree well with the known increase in thyroid hormone synthesis in patients with Graves' disease and also with our previous finding that thyroidal ${ }^{131}$ I uptakes remain elevated even when patients are made euthyroid by drug therapy (9). The fact that iodinating activity of thyroid tissue was not affected by the administration of $T_{3}$ is consistent with the $\mathrm{T}_{3}$ nonsuppressibility known to exist in vivo. In our experience, patients with Graves' disease continue to be nonsuppressible when treated with thionamide drugs for only $3-7$ mo as were the patients in this study (9). The increase in in vitro iodination of thyroglobulin is due mainly to an increase in peroxidase activity in the particulate fraction rather than to differences in the ease of iodination of thyroglobulin. Peroxidase activity should be decreased in the presence of antithyroid compounds whose mechanism of action is mainly blocking iodine organification. Whereas a direct effect of antithyroid drugs can not be ruled out, the peroxidase activity was not changed when rats were sacrificed $1 \mathrm{~h}$ after the injection of propylthiouracil (6), although methimazole may behave differently from propylthiouracil (10). However, in the present experi- ment, the peroxidase activity was increased, not decreased, in patients with Graves' disease during methimazole therapy. If a direct depressant effect of methimazole was present, it was apparently overcome by the increase in the peroxidase activity in patients with Graves' disease. Only 2 of 24 patients with Graves' disease were treated with propylthiouracil but values obtained from these patients were very similar to those with methimazole. Inhibitory substances present in the undialyzed homogenate were not examined in the present experiment, although they may play some role in the regulation of hormone synthesis in thyroid glands of Graves' disease. It should be noted that other factors, e.g. an increased rate of production of $\mathrm{H}_{2} \mathrm{O}_{2}$, may also be important in the increased thyroid hormone synthesis of Graves' disease. However, these factors could not be measured in these experiments.

Changes in peroxidase activity in various thyroid diseases have been reported by many investigators (11-21). In nontoxic nodular goiter, the activity is decreased in cold nodules and increased or remained the same as normal tissue in warm nodules $(11,12)$. In goiters with an iodide organification defect, peroxidase activity is usually decreased (1217), but is normal in Pendred's syndrome $(18,19)$. Nontoxic multinodular goiter has increased peroxidase activity $(19,20)$ and it has been reported in a few patients with toxic diffuse goiter that peroxidase activity per gram tissue is increased much more than DNA content indicating that the activity per cell is increased $(12,19,21)$. It is very likely that changes in peroxidase activity relate to some of the essential changes in hormone synthesis in several thyroidal disorders.

Although thyroidal peroxidase activity was not studied specifically regarding its relationships with $\mathrm{T}_{3}$ suppressibility in this study, it was shown in

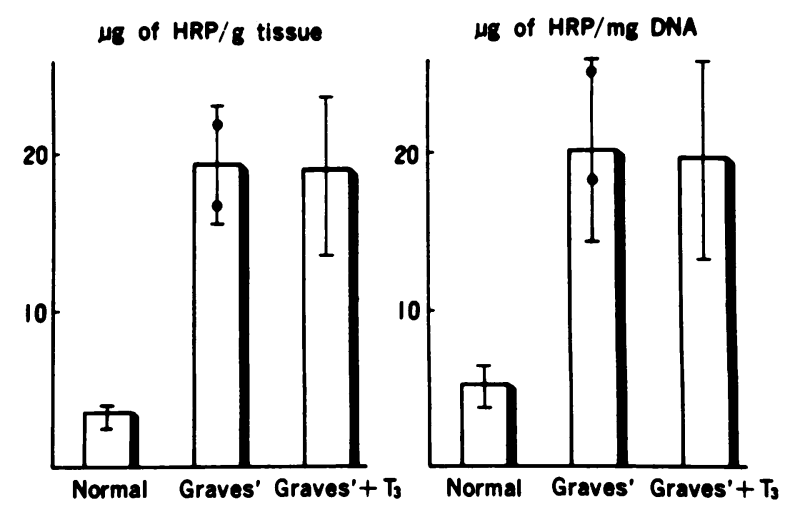

FIGURE 3 Peroxidase activity as guaiacol-oxidizing activity. Values are expressed in terms of an equivalent amount of horseradish peroxidase (HRP). 
intact rats given $T_{3}$ or $T_{4}$, that peroxidase activity was markedly decreased $(6,22)$. The findings in the present experiment that the administration of $T_{3}$ does not affect peroxidase activity in Graves' disease has not been reported earlier and is emphasized because $\mathrm{T}_{3}$ nonsuppressibility is one of the most important characteristics of Graves' disease and may be closely related to peroxidase activity as alluded to previously. Some patients in a group of 24, after 3-7 mo on antithyroid drugs, showed normal iodinating activity. It is very likely that they had already been in remission before surgery. However, since $T_{3}$ suppressibility was not determined in each patient, and peroxidase activity of normal tissue after $\mathrm{T}_{3}$ suppression was not determined, it is not clear whether they were in remission or not in remission.

The administration of TSH stimulates thyroidal peroxidase activity in rats $(6,22,23)$; however, the increase in peroxidase activity in thyroids of patients with Graves' disease is not due to an increase in serum TSH since TSH, $T_{4}$, and $T_{3}$ levels in the patients reported in this study were within the normal ranges and serum TSH concentrations were not detectable after the administration of $T_{3}$.

In the present experiment, the formation of intrathyroidal iodothyronine was not measured, although thyroidal peroxidase stimulates not only the iodination of thyroglobulin, but also the formation of $\mathrm{T}_{4}$ $(7,24,25)$. The localization of peroxidase in thyroid cells is important in relation to its function (26-28), but only values for total peroxidase activity in thyroid tissue were determined in the present study. It was reported that a small percentage of the total peroxidase activity was found in a fraction sedimenting at $600-1,000 \mathrm{~g}(5,6,14,15)$, but the $600-g$ pellet was discarded in this experiment. Furthermore, iodination of thyroglobulin was studied in vitro without turnover of substrates. Despite these points, it can be concluded that the increase in peroxidase activity is one of the essential changes within the thyroid which relates to the possible mechanism of increased thyroid hormone synthesis in Graves' disease. Evidence is currently available to suggest that an extrathyroidal stimulator (e.g. LATS [29], LATS-protector [30, 31], human thyroid stimulator [32], thyroid-stimulating immunoglobulins [33]) is indeed present in circulation of patients with Graves' disease. The extrathyroidal stimulator could cause increased peroxidase activity observed in this study. Other studies to detect an intrathyroidal defect in Graves' disease have failed to find the differences between thyroid tissue of normal controls and patients with Graves' disease, e.g. TSH stimulation of ${ }^{32} \mathrm{P}$ incorporation into phospholipids (34), basal adenyl cyclase, cyclic
AMP concentrations, $\left[1-{ }^{14} \mathrm{C}\right]$ glucose oxidation, ${ }^{32} \mathrm{P}$ incorporation or TSH-increased adenyl cyclase activity, and ${ }^{32} \mathrm{P}$ incorporation (35), intracellular binding characteristics of cyclic AMP (36). However, it remains to be clarified whether the increase in peroxidase activity is due to an extrathyroidal stimulator or due to an intrathyroidal defect.

\section{ACKNOWLEDGMENTS}

Authors are indebted to Mrs. Yoshiko Suzuki and Miss Naoko Kamiyama for their technical assistance, and to Miss Takako Yoshiyuki and Miss Kuniko Kawasaki for their secretarial service. We are grateful to Dr. Sidney $\mathrm{H}$. Ingbar, Thorndike Memorial Laboratory, Beth Israel Hospital, Boston, Mass. for his helpful criticism. Deep gratitude is due to Dr. Yasushi Takagi, and Mr. Atsushi Sugimoto, Radioassay Laboratory, the Dainabot Radioisotope Laboratory, Chiba-Pref. Japan, for their cooperation in measuring serum concentrations of $\mathrm{T}_{4}, \mathrm{~T}_{3}$, and TSH.

This work was supported in part by the Research grant for Specific Disease from the Ministry of Health and Welfare, Japan.

\section{REFERENCES}

1. Salvatore, G., M. Salvatore, H. J. Cahnmann, and J. Robbins. 1964. Separation of thyroidal iodoproteins and purification of thyroglobulin by gel filtration and density gradient centrifugation. J. Biol. Chem. 239: 3267-3274.

2. Inoue, K., and A. Taurog. 1968. Sedimentation pattern of Soluble protein from thyroids of iodine deficient rats; acute effects of iodide. Endocrinology. 83: 816-832.

3. Lowry, O. H., N. J. Rosebrough, A. L. Farr, and R. J. Randall. 1951. Protein measurement with the Folin phenol reagent. J. Biol. Chem. 193: 265-275.

4. Alexander, N. M. 1962. A spectrophotometric assay for iodine oxidation by thyroid peroxidase. Anal. Biochem. 4: 341-345.

5. Hosoya, T., Y. Kondo, and N. Ui. 1962. Peroxidase activity in thyroid gland and partial purification of the enzyme. J. Biochem. (Tokyo). 52: 180-189.

6. Nagataki, S., H. Uchimura, Y. Masuyama, and K. Nakao. 1973. Thyrotropin and thyroidal peroxidase activity. Endocrinology. 92: 363-371.

7. Taurog, A. 1970. Thyroid peroxidase and thyroxine biosynthesis. Recent Prog. Horm. Res. 26: 189-247.

8. Burton, K. 1956. A study of the conditions and mechanism of the diphenylamine reaction for the colorimetric estimation of deoxyribonucleic acid. Biochem. J. 62: $315-323$.

9. Nagataki, S., H. Uchimura, F. Matsuzaki, and Y. Masuyama. 1974. Comparison of the triiodothyronine suppression test by the twenty-minute and the twenty-four-hour thyroidal ${ }^{131}$ I uptake in patients receiving thioamide drugs. J. Clin. Endocrinol Metab. 38: 255-261.

10. Nagasaka, A., and H. Hidaka. 1976. Effect of antithyroid agents, 6-propyl-2-thiouracil and 1-methyl-2mercaptoimidazole on human thyroid iodide peroxidase. J. Clin. Endocrinol. Metab. 43: 152-158.

11. Niepomniszcze, H., N. Altschuler, M. H. Korob, and O. J. Degrossi. 1969. Iodide-peroxidase activity in human thyroid. 1. Studied on non-toxid nodular goiter. Acta Endocrinol. 62: 193-199. 
12. Valenta, L. J., V. Valenta, C. A. Wang, A. L. Vickery, Jr., J. Caulfield, and F. Maloof. 1973. Subcellular distribution of peroxidase activity in human thyroid tissue. J. Clin. Endocrinol. Metab. 37: 560-569.

13. Hagen, G. A., H. Niepomniszcze, H. Haiback, M. Bigazzi, R. Hati, B. Rapoport, C. Jimenez, L. J. DeGroot, and T. F. Frawley. 1971. Peroxidase deficiency in familial goiter with iodine organification defect. N. Engl. J. Med. 285: 1394-1398.

14. Niepomniszcze, H., L. J. DeGroot, and G. A. Hagen. 1972. Abnormal thyroid peroxidase causing iodide organification defect. J. Clin. Endocrinol. Metab. 34: $607-616$.

15. Niepomniszcze, H., S. Castells, L. J. DeGroot, S. Refetoff, O. S. Kim, B. Rapoport, and R. Hati. 1973. Peroxidase defect in congenital goiter with complete organification block. J. Clin. Endocrinol. Metab. 36: 347-357.

16. Valenta, L. J., H. Bode, A. L. Vickery, J. B. Caulfield, and F. Maloof. 1973. Lack of thyroid peroxidase activity as the cause of congenital goitrous hypothyroidism. J. Clin. Endocrinol. Metab. 36: 830-844.

17. Nunez, J., J. Pommier, R. Dominici, B. Rahmoun, D. Deme, and J. Tourniaire. 1976. Peroxidase and thyroglobulins from different goiters. Excerpta Med. Int. Congr. Ser. No. 378. 467-469.

18. Burrow, G. N., S. W. Spaulding, N. M. Alexander, and B. F. Bower. 1973. Normal peroxidase activity in Pendred's syndrome. J. Clin. Endocrinol. Metab. 36: 522-530.

19. Ljunggren, J. G., H. Lindström, and B. Hjern. 1973. The concentration of peroxidase in normal and adenomatous human thyroid tissue with special reference to patients with Pendred's syndrome. Acta Endocrinol. 72: 272-278.

20. Rapoport, B., H. Niepomniszcze, M. Bigazzi, R. Hati, and L. J. DeGroot. 1972. Studies on the pathogenesis of poor thyroglobulin iodination in non-toxic multinodular goiter. J. Clin. Endocrinol. Metab. 34: 822-830.

21. Regard, E., P. Fragu, A. Beaumont, and B. M. Nataf. 1976. Peroxidase activity in human benign thyroid disorders: measure and localization. Excepta Med. Int. Congr. Ser. No. 378. 474-476.

22. Yamamoto, K., and L. J. DeGroot. 1974. Peroxidase and NADPH-cytochrome $\mathrm{C}$ reductase activity during thyroid hyperplasia and involution. Endocrinology. 95: 606-612.

23. Hosoya, T., and S. Matsukawa. 1975. Biochemical studies on the peroxidase activity in the normal and hyperplastic thyroids of rats. Endocrinol. Jpn. 22: 25-34.

24. Lamas, L., M. L. Dorris, and A. Taurog. 1972. Evidence for a catalytic role for thyroid peroxidase in the conversion of diiodotyrosine to thyroxine. Endocrinology. 90: 1417-1426.

25. Pommier, J., D. Deme, and J. Nunez. 1973. Dissociation into subunits of thyroglobulin iodinated by thyroid and horse radish peroxidase. Biochimie (Paris). 55: 263-267.

26. Hosoya, T., S. Matsukawa, and Y. Nagai. 1973. Further studies on the localization of peroxidase in pig thyroid cells. Endocrinol. Jpn. 20: 555-564.

27. Tice, L. W., and S. H. Wollman. 1974. Ultrastructural localization of peroxidase on pseudopods and other structures of the typical thyroid epithelial cell. Endocrinology. 94: 1555-1567.

28. Ekholm, R., L. E. Ericson, and G. Engstrom. 1976. Thyroglobulin exocytosis and iodination. Excerpta Med. Int. Congr. Ser. No. 378. 130-133.

29. Adams, D. D., and H. D. Purves. 1956. Abnormal responses in the assay of thyrotropin. Proc. Univ. Otago Med. Sch. 34: 11-12.

30. Adams, D. D., and T. H. Kennedy. 1971. Evidence to suggest that LATS protector stimulates the human thyroid gland. J. Clin. Endocrinol. Metab. 33: 47-51.

31. Shishiba, Y., T. Shimizu, S. Yoshimura, and K. Shizume. 1973. Direct evidence for human thyroidal stimulation by LATS-protector. J. Clin. Endocrinol. Metab. 36: $517-521$.

32. Onaya, T., M. Kotani, T. Yamada, and Y. Ochi. 1973. New in vitro tests to detect the thyroid stimulator in sera from hyperthyroid patients by measuring colloid droplet formation and cyclic AMP in human thyroid slices. J. Clin. Endocrinol. Metab. 36: 859866.

33. Mukhtar, E. D., B. R. Smith, G. A. Pyle, R. Hall, and P. Vice. 1975. Relation of thyroid-stimulating immunoglobulins to thyroid function and effects of surgery, radioiodine, and antithyroid drugs. Lancet. I: 713-715.

34. Schneider, P. B. 1974. TSH stimulation of ${ }^{32} \mathrm{P}$ incorporation into phospholipids of thyroids from patients with Graves' disease. J. Clin. Endocrinol. Metab. 38: 148150.

35. Field, J. B., P. R. Larsen, K. Yamashita, and R. Chayoth. 1974. Effect of TSH on iodine metabolism and intermediary metabolism in tissue from patients with Graves' disease. J. Clin. Endocrinol. Metab. 39: 942949.

36. Orgiazzi, J., I. J. Chopra, D. E. Williams, and D. H. Solomon. 1975. Evidence for normal thyroidal adenyl cyclase, cyclic AMP-binding and protein-kinase activities in Graves' disease. J. Clin. Endocrinol. Metab. 40: $248-255$. 